\title{
Clinical efficacy of statins in the prevention and treatment of coronary heart disease.
}

\author{
Qiang Chen*, Li-Zhu Chen, Xiao-Hua Guo, Juan Zhang
}

Department of Cardiology, the First Affiliated Hospital of Baotou Medical College, Inner Mongolia Baotou Medical University, Baotou, PR China

\begin{abstract}
Objective: This study aimed to investigate the clinical efficacy of statins in the prevention and treatment of coronary heart disease.

Methods: A total of 130 cases of patients with coronary heart disease were selected as research objects. These patients were admitted in our hospital from February 2015 to January 2017. All patients with coronary heart disease were randomly divided into two groups as follows: control group (n=65), undergoing the conventional therapy of coronary heart disease; observation group ( $n=65$ ), undergoing the conventional therapy+pravastatin/simvastatin. Finally, the efficacies, blood lipid improvement results, treatment satisfaction survey results, and adverse reactions of patients were compared between the two groups.

Results: The efficacy of patients with coronary heart disease in the observation group was significantly increased $(98.46 \%)$ compared with that in the control group $(80 \%)(\mathrm{P}<0.05)$. The blood lipid of patients with coronary heart disease in the observation group was also significantly improved $(P<0.05)$. The treatment satisfaction survey results of patients with coronary heart disease in the observation group were also significantly improved $(98.46 \%)$ compared with that in the control group $(84.62 \%)(\mathbf{P}<0.05)$. Furthermore, the incidence of adverse reactions of patients with coronary heart disease in the observation group was significantly reduced $(\mathbf{3 . 0 8 \%})$ compared with that in the control group $(\mathbf{1 8 . 4 6 \% )}$ (P<0.05).

Conclusion: During the prevention and treatment of coronary heart disease, the rational application of statins can improve the efficacy, blood lipid level, therapy satisfactions, and therapeutic safety so as to alleviate the coronary heart disease and improve the overall efficacy.
\end{abstract}

Keywords: Coronary heart disease, Statins, Efficacy.

Accepted on October 28, 2017

\section{Introduction}

Dyslipidemia is a common cause of coronary heart disease. Statins is commonly applied in the treatment of patients with coronary heart disease [1]. Statins can increase the activity of Low-Density Lipoprotein (LCL) receptor and serum cholesterol clearance of patients to a certain extent [2]. In this regard, the LDL-C level will show significant value in the prevention and treatment of patients with coronary heart disease [3]. The present study aims to investigate the prevention and treatment of patients with coronary heart disease using statins so as to illustrate its clinical value.

\section{Materials and Methods}

\section{General data}

A total of 130 cases of patients with coronary heart disease were selected as research objects. These patients were admitted in our hospital from February 2015 to January 2017. All patients with coronary heart disease were randomly divided into two groups: the control group $(n=65)$ consisted of 32 males and 33 females, aged 49-77 y old (average, $61.39 \pm 2.81$ y) and with an average duration of $6.39 \pm 2.12 \mathrm{y}$; the observation group $(n=65)$ was composed of 30 males and 35 females, aged 51-79 y old (average, 61.41 $\pm 2.82 \mathrm{y}$ ) and with an average duration of $6.42 \pm 2.15 \mathrm{y}$. Patients who were unable to communicate due to cognitive impairment were excluded. Patients with severe brain disease and abnormal liver and kidney functions were also excluded. Gender, age, and duration of patients with coronary heart disease showed no significant difference between the two groups $(\mathrm{P}>0.05)$.

\section{Method}

After admission in the hospital, the patients in the control group underwent conventional therapy, and the patients in the observation group underwent the conventional therapy +pravastatin/simvastatin. Conventional control therapy includes the promotion of the myocardial cell metabolism of 
patients and circulation and stasis removal. In addition, aspirin was used to resist platelet aggregation. Isosorbide dinitrate was used to dilate the vessels effectively. Low-molecular-weight heparin was used to resist the coagulation. The patients in the observation group underwent pravastatin/simvastatin therapy so as to obtain a significant lipid-lowering effect. The patients were advised to take the drug orally (qn, qd). One course lasted for $4 \mathrm{w}$. Two courses were performed. Finally, the efficacies of patients with coronary heart disease were compared between the two groups.

\section{Criteria}

Efficacy criteria: Excellent: All patients with coronary heart disease underwent the dynamic electrocardiogram examination. Arrhythmia was decreased by more than $90 \%$. The patients' chest distress and palpitation were also improved significantly. Valid: All patients with coronary heart disease underwent the dynamic electrocardiogram examination, and the arrhythmia was decreased by more than $50 \%$. Additionally, the patients' chest distress and palpitation were improved. Invalid: All patients with coronary heart disease underwent the dynamic electrocardiogram examination, and the arrhythmia was decreased by less than $50 \%$. The patients' chest distress and palpitation showed no improvement.

\section{Therapy satisfaction survey}

During drug therapy, the satisfaction survey results of all patients with coronary heart disease were categorized into very satisfied, satisfied, and unsatisfied according to the self-made questionnaire. The final total satisfaction rates were compared.

\section{Statistical methods}

The treatment results of all patients with coronary heart disease were analysed using the statistical software SPSS 20.0. Measurement data (lipid level) were expressed using and compared using the t-test between the two groups. The count data (efficacy of coronary heart disease) are expressed in percentage and were compared using the $\chi^{2}$ between the two groups. $\mathrm{P}<0.05$ indicated that the difference was statistically significant.

\section{Results}

\section{Efficacy comparison}

The efficacy of patients with coronary heart disease in the observation group was significantly improved (98.46\%) compared with that in the control group $(80 \%)(\mathrm{P}<0.05)$, as shown in Table 1 .

Table 1. Efficacy comparison of patients with coronary heart disease between the two groups $(n)$.

\begin{tabular}{lllll}
\hline Group & Excellent & Valid Invalid & $\begin{array}{l}\text { Total effective rate } \\
(\%)\end{array}$
\end{tabular}

\begin{tabular}{lccccc}
\hline $\begin{array}{l}\text { Observation } \\
\text { group }\end{array}$ & 65 & 53 & 11 & 1 & 98.46 \\
\hline Control group & 65 & 40 & 12 & 13 & 80.00 \\
\hline$X^{2}$ & & & & & 11.527 \\
\hline$P$ & & & & & $<0.05$ \\
\hline
\end{tabular}

\section{Blood lipid improvement comparison}

The blood lipid of patients with coronary heart disease in the observation group was significantly improved compared with that in the control group $(\mathrm{P}<0.05)$, as shown in Table 2 .

Table 2. Blood lipid improvement comparison of patients with coronary heart disease between the two groups $(\bar{x} \pm s, \mathrm{mmol} / \mathrm{L})$.

\begin{tabular}{lllll}
\hline Group & Time & $\begin{array}{l}\text { Total } \\
\text { cholesterol }\end{array}$ & Triglyceride & $\begin{array}{l}\text { Low- } \\
\text { density } \\
\text { lipoprotein }\end{array}$ \\
\hline $\begin{array}{l}\text { Observation } \\
\text { group }\end{array}$ & $\begin{array}{l}\text { Before } \\
\text { treatment }\end{array}$ & $5.05 \pm 0.65$ & $1.97 \pm 0.75$ & $3.29 \pm 1.02$ \\
\cline { 2 - 5 } & After treatment & $4.30 \pm 0.72$ & $1.55 \pm 0.72$ & $2.45 \pm 0.42$ \\
\hline t-test & & 6.2337 & 3.2569 & 6.1394 \\
\hline$P$ & $<0.05$ & $<0.05$ & $<0.05$ \\
\hline Control group & $\begin{array}{l}\text { Before } \\
\text { treatment }\end{array}$ & $5.03 \pm 0.66$ & $1.96 \pm 0.82$ & $3.29 \pm 1.05$ \\
\cline { 2 - 5 } & After treatment & $4.89 \pm 0.85$ & $1.85 \pm 0.59$ & $3.01 \pm 0.49$ \\
\hline t-test & & 1.0488 & 0.8778 & 1.9482 \\
\hline$P$ & & $>0.05$ & $>0.05$ & $>0.05$ \\
\hline
\end{tabular}

\section{Therapy satisfaction result comparison}

The therapy satisfaction survey result of patients with coronary heart disease in the observation group was significantly improved (98.46\%) compared with that in the control group $(84.62 \%)(\mathrm{P}<0.05)$, as shown in Table 3.

Table 3. Therapy satisfaction survey result of patients with coronary heart disease between the two groups (n).

\begin{tabular}{llllll}
\hline Group & $\mathbf{n}$ & $\begin{array}{l}\text { Very } \\
\text { satisfied }\end{array}$ & Satisfied & $\begin{array}{l}\text { Unsatisfie } \\
\mathbf{d}\end{array}$ & $\begin{array}{l}\text { Total } \\
\text { satisfaction (\%) }\end{array}$ \\
\hline $\begin{array}{l}\text { Observatio } \\
\text { n group }\end{array}$ & 65 & 49 & 15 & 1 & 98.46 \\
\hline $\begin{array}{l}\text { Control } \\
\text { group }\end{array}$ & 65 & 36 & 19 & 10 & 84.62 \\
\hline $\mathrm{X}^{2}$ & & & & 5.8757 \\
\hline $\mathrm{P}$ & & & $<0.05$ \\
\hline
\end{tabular}

\section{Total incidence of adverse reaction comparison}

The total incidence of adverse reaction of patients in the observation group was significantly reduced (3.08\%) compared 
with that in the control group $(18.46 \%)(\mathrm{P}<0.05)$, as shown in Table 4.

Table 4. Total incidence of adverse reaction comparison of patients with coronary artery disease between the two groups (n).

\begin{tabular}{lllll}
\hline Group & $\mathbf{n}$ & $\begin{array}{l}\text { Myocardial } \\
\text { infarction }\end{array}$ & $\begin{array}{l}\text { Coronary } \\
\text { disease recurrence }\end{array}$ & $\begin{array}{l}\text { heart } \\
\text { incidence (\%) }\end{array}$ \\
\hline Observation & 65 & 1 & 1 & 3.08 \\
\hline Control & 65 & 7 & 5 & 18.46 \\
\hline$X^{2}$ & & & & 8.0049 \\
\hline$P$ & & & & $<0.05$ \\
\hline
\end{tabular}

\section{Discussion}

As a significant lipid-lowering drug, statins, which mainly includes simvastatin, fluvastatin, lovastatin, pravastatin, rosuvastatin, and atorvastatin, can exert significant effect on patients with coronary heart disease [4]. Statins is also known as the 5-Hydroxy-3-Methylglutaryl-Coenzyme A (HMG-CoA) reductase inhibitor. $\mathrm{HMG}-\mathrm{CoA}$ reductase, as a cholesterol limiting enzyme, can be synthesized efficiently. Statins shows specific competitive inhibition, and it can completely inhibit the synthesis of cholesterol [5]. In addition, the serum and tissue cholesterol concentrations are significantly reduced. The activity and number of low density lipoprotein receptor are also increased significantly [6]. Thus, the patients' remarkable LDL and LDL metabolism clearances are accelerated. Moreover, the production of substantially low density lipoprotein is significantly decreased, which significantly reduces the level of LDL-C in patients. The interaction between drugs should be given considerable attention during statin treatment. The contraindications for drug treatment should be appropriately defined to ensure statin safety sufficiently $[7,8]$.

The present results showed that the efficacy of patients with coronary heart disease in the observation group was significantly increased $(98.46 \%)$ compared with that in the control group $(80 \%)(\mathrm{P}<0.05)$. The blood lipid level of patients with coronary heart disease in the observation group was also significantly improved $(\mathrm{P}<0.05)$. Additionally, the therapy satisfaction of patients with coronary heart disease was significantly improved $(98.46 \%)$ compared with that in the control group $(84.62 \%) \quad(\mathrm{P}<0.05)$. The total incidence of adverse reactions of patients with coronary heart disease in the observation group of patients with coronary heart disease was significantly reduced $(3.08 \%)$ compared with that in the control group $(18.46 \%)(\mathrm{P}<0.05)$. These findings proved that in the treatment of patients with coronary heart disease, statins could regulate the blood lipid level and myocardial cell autorhythmicity, increase the vascular endothelial function, stabilize the coronary atherosclerotic plaque, and resist the inflammation of myocardial cell and oxidation $[9,10]$. As a result, the patients' condition and the life quality of patients with coronary heart disease were significantly improved. Finally, the accurate efficacy of coronary heart disease was obtained, which effectively proved the value of statins in treatment of patients with coronary heart disease.

\section{Conclusion}

In the prevention and treatment of patients with coronary heart disease, the rational application of statins can improve the efficacy, blood lipid level, therapy satisfaction, and therapeutic safety, thereby guaranteeing the prevention and treatment efficacies.

\section{References}

1. Kones R. Primary prevention of coronary heart disease: integration of new data, evolving views, revised goals, and role of rosuvastatin in management. A comprehensive survey. Drug Des Devel Ther 2011; 5: 325-380.

2. Alkan M. Evaluation of the unintentional firearm deaths and injuries in rural areas. Biomed Res India 2017; 28: 2379-2383.

3. Foody JM, Rathore SS, Galusha D, Masoudi FA, Havranek EP, Radford MJ, Krumholz HM. HydroxymethylglutarylCoA reductase inhibitors in older persons with acute myocardial infarction: evidence for an age-statin interaction. J Am Geriatr Soc 2006; 54: 421-430.

4. Gomes FP, Garcia PL, Alves JMP, Singh AK, KedorHackmann ERM, Santoro MIRM. UV-derivative spectrophotometric and stability-indicating highperformance liquid chromatographic methods for determination of simvastatin in tablets. Lat Am J Pharm 2009; 28: 261-269.

5. Enas EA, Kuruvila A, Khanna P, Pitchumoni CS, Mohan V. Benefits and risks of statin therapy for primary prevention of cardiovascular disease in Asian Indians-A population with the highest risk of premature coronary artery disease \& diabetes. Indian J Med Res 2013; 138: 461-491.

6. Zhang J, Li P, Wang X. Beneficial effect of xanthohumol, a prenylated flavanoid, on 3-nitropropionic acid induced huntingtons disease in a rat model. Lat Am J Pharm 2017; 36: 1867-1874.

7. Vera MAD, Bhole V, Burns LC, Lacaille D. Impact of statin adherence on cardiovascular disease and mortality outcomes: a systematic review. Br J Clin Pharmacol 2014; 78: 684-698.

8. Manikandan G, Bala Krishnan R, Rajesh Kumar N, Sairam N, Raajan NR. A steganographic approach for realizing medical data privacy in a distributed environment. Biomed Res India 2017; 28: 1031-1035.

9. Roberts ET, Horne A, Martin SS, Blaha MJ, Blankstein R, Budoff MJ, Sibley C, Polak JF, Frick KD, Blumenthal RS, Nasir K. Cost-effectiveness of coronary artery calcium testing for coronary heart and cardiovascular disease risk prediction to guide statin allocation: the multi-ethnic study of atherosclerosis (MESA). PLoS One 2015; 10: 0116377.

10. Neil A, Cooper J, Betteridge J, Capps N, McDowell I, Durrington P, Seed M, Humphries SE. Reductions in allcause, cancer, and coronary mortality in statin-treated 
patients with heterozygous familial hypercholesterolaemia: a prospective registry study. Eur Heart J 2008; 29: 2625-2633.

\section{*Correspondence to}

Qiang Chen
Department of Cardiology

The First Affiliated Hospital of Baotou Medical College Inner Mongolia Baotou Medical University

PR China 